\title{
De Jean de Léry a Claude Lévi-Strauss: por uma arqueologia de Tristes trópicos
}

\author{
Frank Lestringant \\ Université Paris IV - Sorbonne
}

\begin{abstract}
RESUMO: A comparação entre a História de Duas Viagens ao Brasil, de Jean de Léry, e Tristes trópicos, de Claude Lévi-Strauss, mostra entre os autores e suas narrativas acerca do Brasil numerosos paralelos. No modo de se relacionar com o Brasil, na descrição dos índios, na própria forma de construir seu texto, Léry aparece como um predecessor de Lévi-Strauss. Mais do que retomar a narrativa de Léry, Lévi-Strauss estabelece com ela um diálogo, no qual se pode também perceber as divergências de ponto de vista entre os autores, envoltas nas lembranças nostálgicas de ambos de suas estadas no Novo Mundo.
\end{abstract}

PALAVRAS-CHAVE: Jean de Léry, Claude Lévi-Strauss, narrativas de viagem, imagens dos índios.

\section{Juventude e agonia do Novo Mundo}

No final de sua aula inaugural no Collège de France, em janeiro de 1960, Claude Lévi-Strauss lamentava:

Como é possível que a etnografia não tenha recebido seu lugar quando ainda era jovem, e os fatos guardavam sua riqueza e seu frescor? Pois em 1558 é que se gostaria de imaginá-la estabelecida, quando Jean de Léry, voltando do Brasil, redigia sua primeira obra, e quando apareciam Les singularités de la France Antarctique de André Thevet ${ }^{1}$. (1976: 38) 
Juventude e frescor do mundo no tempo de Léry, como de uma aurora que não tivesse realizado suas promessas. Juventude de uma disciplina que acabava de florescer do outro lado do Atlântico e que ainda não tinha recebido nome. A ilusão retrospectiva é tão poderosa que marca a obra e a vida do antropólogo. Podemos vê-la expressa com todo o seu vigor na entrevista realizada por Dominique-Antoine Grisoni para servir de prefácio a uma edição recente da História de uma viagem à terra do Brasil:

A leitura de Léry me ajuda a escapar de meu século, a retomar contato com o que eu chamaria de "sobre-realidade", não aquela de que falam os surrealistas, mas uma realidade ainda mais real do que aquela que testemunhei. Léry viu coisas que não têm preço, porque era a primeira vez que eram vistas e porque foi há quatrocentos anos. (Léry, 1994: 13)

A presença alucinatória do índio em Léry nos transporta para um outro tempo, que é o tempo das origens. Permite-nos viver esse milagre. A História de uma viagem à terra do Brasil, publicada em 1578 em Genebra, vinte anos após seu autor ter retornado do Brasil, representaria nesse sentido o auge da literatura de evasão, a obra-prima acabada do gênero. Ao lê-la, como por magia, poder-se-ia escapar do triste presente e recuperar a euforia dos princípios, quando tudo ainda era possível e, do outro lado do oceano, a humanidade que surgia ainda não estava condenada, prematuramente desgastada, assassinada na infância por uma conquista das mais horríveis.

O charme e a eficácia da História de Léry viriam primeiramente do fato de se tratar de um "relato de primeiro encontro". Primeiro, se fizermos abstração do precedente, de André Thevet, nada desprezível, ao contrário do que afirma Léry. Seria inútil denunciar a ilusão em que se enraiza o comentário. Na verdade Léry, à diferença de Montaigne, não tinha a impressão de descobrir um mundo na infância, "ainda nu no seio da mãe nutriz” (Montaigne, 1965: 908). Seu Brasil é um mundo já velho; a humanidade que nele habita pertence indubitavelmente à "raça corrompida de 
Adão". A maldição que sobre ela pesa só será afastada com a condição de uma conversão, bastante improvável, ao cristianismo. A tentação do primitivismo existe em Léry, assim como em Lévi-Strauss. Contudo, em ambos, talvez mais no autor da História do que em seu longínquo êmulo, a tentação é conjurada, como "contida" pela constatação da degradação universal - da "piora" diria Léry, da degeneração, teria dito Gobineau. "Regressivos são os Nambiquara", que no entanto oferecem, em seu despojamento absoluto, a imagem perfeita da humanidade primitiva (LéviStrauss, 1994b: 15). Seu estado atual, pior do que nos anos 30, é na verdade o resultado de uma decadência acelerada pela Conquista. O mesmo ocorre com os Caduveu, os Bororo e a maior parte das outras tribos visitadas pelo etnólogo no entre-guerras. Para Léry, essa decadência é um fato incontestável, cuja origem é bem mais remota, situada imediatamente após o pecado original. Provas disso são as perdas de memória dos índios, o esquecimento das artes e técnicas e, principalmente, da Palavra. De modo que a impressão de inocência que se desprende da História poderia ser enganosa. Trata-se sobretudo de um efeito da retórica que visa acusar por ricochete a perversidade bem maior da Europa. Em vez de realidade, um artifício, mais poderoso na medida em que se vale das desilusões da época. Se infância há no Novo Mundo, já se encontra há muito tempo corrompida. A única juventude na História é a do herói e narrador que, posteriormente amadurecido antes do tempo, envelhecido pela sucessão de provações das guerras de religião, não pára de lembrar e de sentir saudades. Mas não se trata, mais uma vez, de uma ilusão?

A História de Léry busca recuperar uma presença perdida. Recorrendo à enargeia - à "evidência" no sentido retórico -, o texto incorpora todo o poder da imagem. Leva a ver, mais do que permite ler. Coloca diante dos olhos uma realidade abolida pelo tempo e pela distância. O que não impede Léry de lamentar constantemente o fracasso de sua empresa. Como por exemplo no final do capítulo sobre os animais terrestres, no qual censura o camarada Jean Gardien, um "de nossa companhia, especialista na arte de retratar", por não ter aquiescido ao seu pedido de "representar" a fauna 
do Brasil desconhecida na França(Léry, 1994: 275) . Como, sem o auxílio do desenho, dar uma idéia do coati, animal "estranhamente defeituoso, se comparado aos de nossa Europa"? Do mesmo modo, para concluir o capítulo VIII, tendo finalizado a ekphrasis do desfile de vestimentas, Léry insiste na distância entre seu esforço de memória e a pobreza do resultado obtido no tocante aos selvagens, grandes e pequenos, sua nudez, suas atitudes, suas constantes movimentações: "terei sempre na memória a idéia e a imagem deles, contudo, porque seus gestos e modos são em tudo diversos dos nossos, confesso que é difícil representá-los bem, seja por escrito, ou até mesmo pela pintura" (:234). A escrita é, definitivamente, trabalho de luto.

A observação de Lévi-Strauss tenderia a provar que Léry se enganou. Por excesso de modéstia, ele teria subestimado o sucesso literário de seu livro. Poderíamos então indagar se essas confissões de fracasso retomadas não fazem parte de uma estratégia global, e se a constatação de imperfeição, apesar de seu aspecto ligeiramente irônico, não visa precisamente completar o dispositivo. Trata-se de um pedido de ajuda dirigido ao leitor, solicitado a continuar o gesto inacabado da restituição. Isso é comum, aliás, no procedimento da enargeia. A insistência na operação em curso, a proliferação dos indicadores de regência fingem uma distância crítica para melhor aboli-la em seguida, num jogo sutil e sempre à beira da perda de equilíbrio, entre distanciamento desconfiado e adesão cega ${ }^{2}$. Chamado a cooperar com a ilusão, o leitor entra, quer queira quer não, no jogo da alucinação compartilhada. O exemplo de Lévi-Strauss leitor de Léry mostra que o dispositivo funciona perfeitamente, apesar do intervalo de quatro séculos.

A ilusão nesse caso é reforçada pelo fato de se sobreporem duas experiências do Brasil, de perda e de luto. A História de uma viagem de Léry atravessa em filigrana Tristes trópicos, legível de ponta a ponta nesta viagem em palimpsesto. Nas evocações da calmaria (Léry, 1994: 138; Lévi-Strauss, 1996: 69-70), do estojo peniano (: 215-6; : 270), da pintura facial de índios e índias (: 230; : 167-86), dos "lagos de amor" e outros 
motivos geométricos que florescem nos rostos e na cerâmica $(: 447 ;$ : 167 86), da fabricação do cauim fermentado pela saliva das virgens (: 247-8; :330), da cor de azeviche das penas do mutum (:278; :312), das araras depenadas das aldeias bororo em que o estrangeiro tropeça ao acordar (:280;: 205), das abelhas que se amontoam sobre os olhos sem causar danos (:290;: 254), dos grilos roedores com quem convivem há séculos os Tupi-Kawahib (:291; : 332), das lascas afiadas de bambu que estes mesmos índios utilizam para defender suas aldeias e fazer armadilhas para os inimigos (: 346; : 327), a referência a Léry é constante, regular, subjacente. Pode-se percebê-la ainda no elogio da poligamia indígena, que não impede a mulher e as concubinas de um mesmo chefe de viverem em paz umas com as outras (: 427-8; : 296), na alusão discreta e bemhumorada ao homossexualismo dos rapazes $(: 430 ;: 337)$, ou nos nomes tirados de coisas ou de animais $(: 431 ;: 262)$.

A proximidade não se limita ao universo “objetivo" dos índios, idêntico, ou quase, apesar da passagem dos séculos e da catástrofe da colonização e do genocídio, estende-se ao domínio subjetivo da emoção. O cauim ou chicha de milho continua "intermediária entre a cerveja e a sopa" e sua degustação acompanhada de uma repugnância instintiva (Léry, 1994: 2478; Lévi-Strauss, 1996: 314). Os cantos cadenciados dos índios causam, com quatro séculos de intervalo, o mesmo encanto. Para Lévi-Strauss como para Léry é pura alegria e "uma maravilha escutá-los" (: 403; : 205). A admiração pelas danças é sentida com particular intensidade pelo segundo, que fala do "deslumbrante cotilhão metafísico dos Bororo" (: 406; : 228). O capítulo XVII da História de uma viagem, que nos faz penetrar na intimidade feliz da família Tupinambá anuncia, para além do Emílio de Rousseau, o extraordinário idílio Nambikwara descrito no capítulo "Em família” de Tristes trópicos (Lévi-Strauss, 1996: 265-77) . Em ambos, a atração sexual age com força sobre o observador, que evoca, em sua defesa, o paradoxal pudor da nudez indígena, inclusive nos enlaces mais carinhosos (Léry, 1994: 437; Lévi-Strauss, 1996: 270) . "O prazer buscado parece mais lúdico e sentimental do que de ordem física”, 
escreve por exemplo Lévi-Strauss. Submetido à proximidade insolente e juvenil das moças Nambikwara, este é no entanto franco ao afirmar que às vezes se torna difícil manter o sangue-frio (: 438; : 270). Léry (1994: 234-6), em situação idêntica, se fechava numa impassibilidade de princípio, desviando a atenção do leitor, in extremis, para o espetáculo infinitamente mais censurável das mocinhas européias, indecentes embora cuidadosamente vestidas (ibidem).

Assim, Léry fornece previamente a Lévi-Strauss não apenas um repertório de atitudes e sentimentos, mas um espelho no qual o etnólogo do século $\mathrm{XX}$ se reconhece em cada detalhe, e pode encontrar nessa volta pelo Renascimento o caminho mais direto para a sinceridade. Tal como se expressa em Tristes trópicos, o amor pelos índios do Brasil passa em grande parte por Léry, que serve ao mesmo tempo de guia, iniciador e quase um irmão mais velho para o viajante moderno.

Porém, o sentimento expresso diante do outro nem sempre é tão eufórico. A desconfiança ou até mesmo o medo surgem em momentos como aquele em que o parceiro indígena demonstra repentinamente agir de má-fé numa troca, ameaçando e insultando com gestos e palavras. Mas mesmo aí, parece que Léry conduz seguramente seu remoto êmulo até a solução satisfatória da questão (Léry, 1994: 467; Lévi-Strauss, 1996: 346-8).

É finalmente na conclusão da viagem, no olhar retrovertido sobre o idílio vivido entre os índios, que Lévi-Strauss se lembra de Jean de Léry. "Lamento amiúde não estar entre os selvagens" (Léry, 1994: 508), confidência sem paralelos na literatura de viagem do século XVI, ainda que seja impossível dissociá-la de seu contexto moral e polêmico. Trata-se, para Léry, de estigmatizar a ingratidão da mãe-pátria, por meio do mais afastado e do mais bárbaro. De qualquer modo, as "saudades" de Jean de Léry inauguram um futuro filosófico dos mais fecundos.

Em sua conclusão da Aula Inaugural de 1960, Lévi-Strauss nos convidava ao mesmo tempo a "renovar" e "expiar" "a Renascença, para estender o humanismo à medida da humanidade" (1976: 39). Ao reescrever a História de uma viagem, variando ampliando esse testemunho fundado na nostalgia 
Revista de Antropologia, São Paulo, USP, 2000, v. 43 nº 2.

e no remorso, Tristes trópicos certamente renova o Renascimento em sua dimensão mais generosa. Igualmente na medida em que herda da História a parte insondável do luto, a segunda obra retoma o ritual de expiação no ponto em que a primeira o havia deixado, e o prolonga, alimentando-o com toda a amargura da má consciência pós-colonial.

\section{Vidas paralelas}

A superposição de Tristes trópicos a História de uma viagem é ainda mais fácil na medida em que de saída dois destinos se identificam. LéviStrauss mostrou-se sensível aos acasos que fizeram que ele cruzasse diversas vezes a aventura terrestre de Léry. Em sua entrevista-prefácio à obra de Léry, Lévi-Strauss reconhece ter

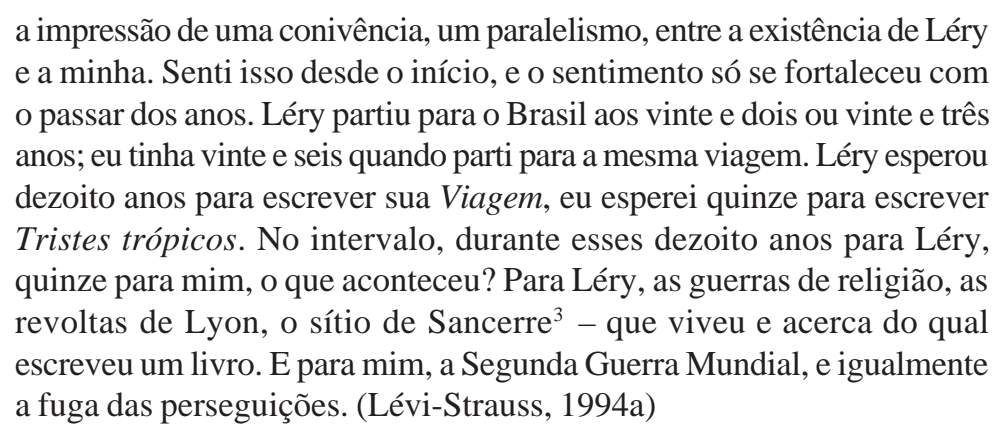

Percebe-se uma espécie de quiasma existencial entre essas duas vidas: de um lado, um huguenote que se tomava por um judeu dos primórdios, isolado no deserto onde teria a experiência mística de sua eleição; do outro, um francês de origem judaica que gostaria de ter sido aquele huguenote do século XVI, exilado longe da Europa em guerra e refugiado numa terra selvagem. Entre o protestante do Renascimento e o judeu de hoje, as tragédias renovadas da história garantem muito mais do que uma conivência, uma profunda identidade de destinos. As guerras de religião, cuja violência culminou no massacre de huguenotes conhecido como noite de São 
Bartolomeu, e o Holocausto, ou melhor, a destruição dos judeus europeus pelos nazistas, representam, apesar da diferença de escala, traumas idênticos que atravessaram essas vidas paralelas e secretamente unidas por sobre o intervalo de séculos. Daí a "intimidade” que Lévi-Strauss descobre em sua relação com Léry. Para ambos, a viagem ao Brasil aparece retrospectivamente como uma experiência iniciática, uma breve escala num aparente paraíso antes das desilusões e provações da história.

O paralelismo é certamente um pouco forçado. Lévi-Strauss dispõe, em relação a Léry, de um excedente temporal que lhe abre um campo mais vasto para a investigação e uma perspectiva crítica mais lúcida. Esses quatro séculos a mais constituem uma vantagem epistemológica considerável. $\mathrm{Na}$ verdade, as vidas paralelas de Léry e Lévi-Strauss se inscrevem numa relação de inclusão: Lévi-Strauss se identifica com um calvinista do século XVI que se via como um judeu do segundo milênio antes de Cristo. Ao descobrir sua "intimidade" com Léry, ao voltar, com ele, para o tempo mítico do Antigo Testamento e comungar com o "Judeu imaginário", "circuncidado espiritual” no sentido do apóstolo Paulo, Claude Lévi-Strauss redescobre suas verdadeiras origens, a família judia em Bruxelas que ele evoca muito discretamente em alguns de seus últimos livros. Em outras palavras, Léry é para Lévi-Strauss a mediação e o desvio que o levam de volta a si mesmo, ou mais precisamente a um antes dele mesmo, à préhistória coletiva de sua história individual.

Dada essa "intimidade" de fundo, as diferenças ganham ainda mais relevo e, seríamos tentados a dizer, significação. Os aparentes desacordos entre Léry e Lévi-Strauss se referem principalmente à escrita e à imagem.

\section{Lições de escrita}

No tocante à questão da escrita, os dois autores parecem se opor diametralmente. Para Léry, a escrita deve ser colocada "no rol dos dons singulares que os homens receberam de Deus" (1994: 382). Os índios que a ignoram e por conseguinte não têm acesso à Bíblia são, ao contrário, 
"um povo maldito e abandonado por Deus" (: 420). A esse elogio da escrita, invenção quase divina, em Léry, corresponde, em Lévi-Strauss, um verdadeiro processo, na famosa "lição de escrita" de Tristes trópicos. A lição que o antropólogo tira é a de que a escrita "parece favorecer a exploração dos homens antes de iluminá-los" (Lévi-Strauss, 1996: 280-4). Em consequiência do subterfúgio empregado por um chefe esperto demais que, para fundamentar sua autoridade, imita o gesto de escrever e rabisca linhas sinuosas sobre o papel, "a escrita e a perfídia penetravam de mãos dadas" entre os Nambikwara. Essas páginas tão paradoxais quanto inspiradas sem dúvida mereceram ser criticadas por seu lado radical, radicalmente "primitivista" (Derrida, 1967: 149-202).

Nesse ponto, Lévi-Strauss retoma um preconceito filosófico antigo, expresso, principalmente em Platão e Plutarco, pela voz de Sócrates. Este último insistia na perda de memória viva, e portanto de conhecimento e inteligência, que a invenção da escrita teria acarretado. A escrita, na perspectiva de Lévi-Strauss, que é a de Rousseau, implica a renúncia à transparência original. Ela introduz a distância e a duplicidade entre os seres, funda uma divisão e uma hierarquia entre os que sabem e os que não sabem escrever.

A crítica antiga da escrita incidia sobre um ponto ligeiramente diferente. A escrita, para o Sócrates de Fedra, é um simulacro do discurso vivo e com alma. Tal simulacro é mentiroso, pois embora se apresente como vivo, é inerte e mudo, como as pinturas que de longe parecem vivas mas "calamse majestosamente quando são interpeladas" (Platão, 1950: 76). A escrita, além de muda, é surda. É incapaz, prossegue Sócrates, de se abrir para o intercâmbio e para o diálogo: se interrogamos os discursos escritos "acerca de um determinado ponto do que dizem, com o intuito de nos instruirmos, é uma única coisa o que dão a entender, uma só, e sempre a mesma"! O que também quer dizer que a escrita não sabe se defender sozinha. Se for duramente atacada, precisa de seu "pai" para responder em seu lugar. Medrosa, fraca e paralisada, além de sofrer de psitacismo e gagueira, a escrita dá as costas à dialética e, portanto, à busca da verdadeira sabedoria que cada qual traz em si. 
Sócrates finalmente censura a escrita por ser uma memória externa, alheia à alma e aos recursos da reminiscência. A constituição dessa memória externa, fria e inerte tem por conseqüência, a seu ver, o definhamento do outro, quente e íntimo, inscrito em cada um de nós. Assim a escrita favorece, além da preguiça e do esquecimento de si, o abandono do tesouro escondido em cada indivíduo. Essa foi, aliás, aproximadamente a resposta do rei do Egito Thamus Amon a Teuth, originário de Naucratis, inventor mítico da escrita: "Pois essa invenção, ao dispensar os homens de exercerem sua memória, produzirá o esquecimento na alma dos que dela tiverem adquirido o conhecimento; confiantes na escrita, buscarão no exterior, graças a caracteres estrangeiros, e não no interior, graças a eles mesmos, o meio de se lembrarem" (: 75).

Léry vai responder a Sócrates. Num adendo à terceira edição, procura refutar a tese paradoxal segundo a qual, longe de servir à memória, a invenção da escrita a teria grandemente prejudicado. Ele chega a espantarse que um "filósofo sábio da Grécia" tenha podido defender tão "estranha" opinião (Léry, 1994: 382, nota 2). E rebate com a opinião de Cícero, que define a história como "mãe dos tempos". Léry invoca Moisés, suposto autor do Pentateuco, "o primeiro escritor" segundo a tradição judaico-cristã resumida no livro Dos inventores de Polidoro Virgílio. Os "antigos pais", ou seja, os patriarcas da Bíblia, de Abraão a José, certamente tinham boa memória; lembravam "muitas boas coisas que, sem outro registro além do entendimento, passavam de pai para filho: mas com muito mais certeza isso se fez depois de estar a escrita em uso".

A crítica que Sócrates dirige à escrita não é pertinente para Jean de Léry, simplesmente porque a relação entre palavra e escrita já não se coloca em termos de antagonismo e exclusão. Para esse calvinista militante, a Palavra e a Escritura são uma única e mesma coisa. A Bíblia não é de modo algum um simulacro mudo, letra morta. É depositária da Palavra viva. A Bíblia fala ao leitor, contanto que este a receba e escute com fé. Opondo-se abertamente à afirmação de Sócrates, de que a escrita seria uma relíquia morta da palavra, relevo inerte do grande festim das palavras, Léry, na 
condição de "predicante", proclama a letra viva de um texto. Assim quer sua vocação, já que é ministro da Palavra. Seu ofício de pastor consiste em reativar uma mensagem sempre já escrita, em fazer ressoar no século presente a boa nova, atestada e confirmada pela tradição escrita.

Além disso, a crítica de Sócrates não se sustenta: por mais que o texto seja transmitido de modo intangível através dos séculos e das distâncias, isso não implica que o discurso escrito seja necessariamente idêntico a si mesmo. Cabe a cada leitor apropriar-se dele e torná-lo seu. Erasmo, em seu Ecclesiastes publicado em 1535, chega a sugerir, não sem audácia, uma leitura aberta e plural do texto sagrado:

Mesmo nos lugares em que a autoridade da Escrita Canônica não nos fez descobrir nenhuma alegoria, não será acusado do crime de sacrilégio alguém que proponha, movido por sincero zelo e sem vã emulação, um sentido no qual talvez não tenha pensado, naquele ponto, o que escreveu o trecho. (Apud Hallyn, 1994: 30)

A boa intenção do leitor, seu zelo e sua fé fazem surgir sentidos que o autor não previra, adormecidos, por assim dizer. Como constata Fernand Hallyn, "é menos importante para o leitor querer encontrar o autor do que descobrir a si mesmo em sua leitura" (1994: 32). Quando, no Prólogo de Gargantua, Rabelais por sua vez convida a abrir a caixa ou a garrafa, ou ainda a roer o osso, age como herdeiro dessa confiança na fecundidade do significante escrito ou literário.

Outra objeção socrática não se sustenta. $\mathrm{O}$ discurso escrito se presta ao questionamento dos interlocutores e se adapta às mais diversas circunstâncias. Basta lembrar aqui o uso da "profecia" por Calvino, uma espécie de adaptação reformada da bibliomancia ou "sortes virgilianas". Na Genebra reformada do século XVI, a "profecia" designava um estudo bíblico prévio, no qual pastores e doutores reunidos, depois de invocarem o Espírito Santo, liam uma página das Escrituras, "deduzindo-lhe o sentido atual, o engajamento concreto que o texto iria exigir tanto do predicante como dos fiéis" (Soulié, 1977: 41). Em seguida, cada um ia pregar a partir 
do texto assim "reavivado". Léry multiplica essas "profecias" em seu próprio discurso, quando revive a Bíblia nas peripécias de sua viagem e nas mais ínfimas singularidades do Brasil.

Não resta dúvida de que em Léry a escrita goza de um privilégio exorbitante, reunindo em si o poder conservador e dominador do traço escrito e a eficácia, a prontidão sempre presentes do verbo. Sócrates considerava a escrita como simulacro ou ilusão, espécie de cadáver da memória; para o calvinista Léry, ela é plena da palavra que encerra e reproduz à vontade, não de forma mecânica, mas por meio de uma fecundidade inexaurível, na improvisação contínua, nas variações sempre atualizadas.

Jacques Derrida, em sua crítica ao logocentrismo herdado de Platão, logocentrismo facilmente perceptível na "lição de escrita" de Claude LéviStrauss, propõe inscrever a palavra na escrita, ou mais precisamente reconhecer escrita em toda linguagem, uma vez que haja obliteração do nome próprio e diferença classificatória. Haveria assim escrita "desde o alvorecer da linguagem". Tal "arquiescrita" é de saída habitada pela violência e pela alienação - a différance. À expressão "sociedade sem escrita", cara à antropologia, "não corresponderia nenhuma realidade nem nenhum conceito" (Derrida, 1967: 161). Essa expressão, prossegue Derrida, "remete ao onirismo etnocêntrico, abusando do conceito corrente, isto é, etnocêntrico, da escrita".

Jean de Léry certamente não escapa do etnocentrismo denunciado por Derrida. Aliás, quem pode ter certeza de fazê-lo? Seu conceito de escrita é restritivo e tipicamente europeu na medida em que desconsidera signos não alfabéticos. Mas é ao mesmo tempo amplo, pois que não é exclusivo da palavra e a contém sem esgotá-la, restituindo-a, ao contrário, indefinidamente.

Por isso o etnocentrismo de Léry se exerce na verdade num sentido muito diferente do do antropólogo que nele se reconheceu. É um etnocentrismo mais brutal na aparência. Em vez de se orientar, num devaneio nostálgico, em direção à origem e à transparência perdidas, aumenta a diferença. As línguas do Paraíso fascinaram o século XVI, mas Léry, um bom calvinista, 
não se permite especular a esse respeito nem, sobretudo, querer retornar a essa origem inatingível. O Paraíso terrestre é, necessariamente, um Paraíso perdido. De certo modo, a imagem idílica do Brasil, essa variante degradada do Éden, confirma isso. O verme está no fruto, desde o pecado original. A serpente está escondida no jardim. O Brasil, nos conta Léry, está repleto de serpentes, "grossas como um braço de homem e longas de uma vara", ou "compridas e delgadas, verdes como a acelga". As primeiras são consumidas, cortadas em postas como enguias; as outras são muito venenosas (1994: 268).

A mensagem de Léry pode ser resumida do seguinte modo: a palavra é enganosa desde o Éden e a tentação de Eva. A escrita não acarreta nenhuma perda, mas ao contrário, a possibilidade de redenção. Infelizes, portanto, os que não dominam a escrita!

Entre as "lições de escrita" de Léry e Lévi-Strauss observa-se, assim, uma espécie de simetria invertida: a escrita é celebrada pelo primeiro na mesma medida em que é desvalorizada pelo segundo. Para um, somente ela contém a plenitude do sentido; para o outro, é simulacro e enganação. Os dois concordam, contudo, em dizer que se trata de um notável instrumento de poder e dominação, o primeiro para vangloriar-se disso, o segundo para melindrar-se. Entre a História de uma viagem e Tristes trópicos haveria, assim, uma simples inversão da lição de escrita: os índios de Léry vêem truque e "feitiçaria" onde há verdade (1994: 380), os de Lévi-Strauss tomam por verdadeiro algo que é uma mentira evidente, um subterfúgio grosseiro, efeito de "perfídia".

Para os dois viajantes no Brasil, a escrita traça uma linha divisória entre dois tipos de sociedades, "frias" ou "quentes" diria o etnólogo moderno, as que só se comunicam "pela palavra”, para falar como Léry, e as que dispõem da escrita para transmitir seus segredos "de um a outro extremo da terra" (: 382). Mas longe de ater-se a essa distinção em que vê um privilégio e uma boa razão para louvar a Deus, Léry, cuja reflexão crítica de certo modo anuncia a de Derrida, considera por outro lado que sendo a lei universal e não podendo ninguém ignorá-la, os índios não são tão 
ignorantes quanto querem fazer crer. Noutras palavras, o fato de não saberem ler nem escrever não constitui garantia de inocência, muito pelo contrário. Independentemente da "arte da escrita", cuja posse é um dom divino reservado a alguns povos, existe uma outra escrita espalhada nas coisas, cujo desconhecimento é imperdoável.

Trata-se do "livro do mundo", legível até na mais ínfima das criaturas, numa folhinha ou numa formiga. Herdeiro de um topos que atravessa toda a Idade Média, de Alain de Lille a Raymond Sebond (Curtius, 1956: cap. XVI), Calvino, no primeiro capítulo da Instituição da religião cristã, reconhece que Deus "gravou em cada uma de suas obras certos sinais de sua majestade, pelos quais se nos dá a conhecer segundo nossa pequena capacidade" (Calvin, 1961: 52). Léry segue fielmente a lição de Calvino quando condena a ingratidão dos brasileiros, incapazes de adorar, embora tenham olhos para ver (1994: 335) . E Deus sabe o quanto esse livro de plantas e árvores, animais e pássaros, exibe pelo Novo Mundo afora, e especialmente sob os trópicos, suas páginas mais ricamente ilustradas!

\section{A imagem, do pleno ao vazio}

As mesmas divergências surgem quanto ao papel e ao poder da imagem. Censurando a preguiça de seu correligionário Jean Gardien, Léry lamenta não ter constituído no Brasil um registro iconográfico. Como pode o seu leitor reconhecer aquilo que só ele viu - e viu com seus próprios olhos -, a evidência que transborda qualquer descrição? Lévi-Strauss, ao contrário, como todo etnólogo competente, fez uma provisão de imagens. Filmou e fotografou o quanto pôde durante suas várias viagens pelo Brasil, "pedaços de filme" em 8 mm e "algo como três mil negativos", entre os quais selecionou, para a publicação, 180 em preto e branco. Mas o resultado não o deixou mais satisfeito do que Léry. A abundância de imagens leva igualmente a uma decepção. Assim, ele constata logo no início de Saudades do Brasil: 
Revista de Antropologia, São Paulo, USP, 2000, v. 43 nº 2.

\begin{abstract}
Examinadas de novo, essas fotografias me dão a impressão de um vazio, de uma falta daquilo que a objetiva é intrinsecamente incapaz de captar. (1994b: 9)
\end{abstract}

O clichê fotográfico, longe de restituir a vida em si, aponta para uma falta, denuncia uma ausência, em resumo, respalda uma impostura. Os clichês não são um fragmento de experiência que teria escapado milagrosamente do trabalho destruidor do tempo, são apenas indícios dela, indícios arrancados de seus contextos e por isso estranhamente mutilados:

Indícios de seres, de paisagens e de acontecimentos que sei ainda que vi e conheci; mas após tanto tempo, nem sempre me lembro onde ou quando. Os documentos fotográficos me provam sua existência, sem testemunhar a seu favor nem torná-los sensíveis a mim. (Ibidem)

Poderíamos pensar que nesse ponto, como em relação à escrita, Léry e Lévi-Strauss pensam de modo oposto. Léry faz o elogio da escrita, que é memória e poder, e vê a imagem como um auxiliar indispensável do texto na conservação do passado ou, o que dá na mesma, do longínquo. Lévi-Strauss, ao contrário, descredita a escrita, como meio de enganar e oprimir, e recentemente, em seu último livro, que no entanto é um livro de imagens, denuncia a "imagística muda" de clichês sem significado e sem substância.

Ora, em toda a obra de Lévi-Strauss, não há certamente livro mais "escrito" do que Tristes trópicos, que denuncia a impostura fundamental da escrita. Quanto ao arquivo iconográfico reunido em Saudades do Brasil, é difícil concordar com o autor e fotógrafo quando ele afirma que "a objetiva é intrinsecamente incapaz de captar" a realidade indígena.

Seria contudo simplista ver aí apenas puros paradoxos. As divergências entre os dois escritores são reais, mas refletem menos uma oposição do que nuanças de interpretação a partir de uma mesma constatação fundamental. A morte realiza sua tarefa, inexoravelmente. Morte dos indivíduos, morte dos povos, morte de toda a espécie. Da vida remota, mistério apenas entrevisto, nem o escrito nem a imagem, quer seja desenhada, gravada ou 
impressa pela luz, são capazes de captar a essência fugidia. Diante do que diz Lévi-Strauss, a confiança que Léry deposita na escrita e no "retrato" desenhado in loco parece-nos no mínimo exagerada.

A verdade é que, tratando-se da escrita e da imagem, os dois autores não falam da mesma coisa, o que explica que um espere delas tanto, e o outro, ao contrário, tão pouco. A escrita, para o reformado Léry, comporta a promessa de uma redenção. Já é, por assim dizer, a ressurreição em marcha. Longe de se ater à letra que mata, como as que se encontram numa correspondência entre conquistadores espanhóis, que condenam sem que ele o saiba o próprio indígena que as transporta ${ }^{5}$, a escrita é transportada, inspirada, preenchida e transbordada pelo espírito que a vivifica. Para Claude Lévi-Strauss, pelo menos no capítulo já estudado de Tristes trópicos, a escrita sujeita as almas e abre o caminho para a servidão dos corpos.

A imagem, por sua vez, tampouco é da mesma natureza nos dois casos. Léry pensa numa cópia fiel da realidade, não através de um procedimento mecânico como a fotografia, mas através do processo mediado da miniatura e do trompe l'oeil. As únicas imagens de que podia dispor um homem do século XVI eram reconstruções mais do que reproduções do real. A intelecção desempenhava um papel preponderante, ao passo que é sempre sumária na técnica fotográfica ${ }^{6}$. As imagens que Léry queria ter para ajudálo na "demonstração" do Brasil não eram instantâneos: resultavam necessariamente da mediação de uma inteligência e de um savoir-faire, por mais imperfeitos que fossem. De modo que elas ofereciam algo como sínteses aproximativas do objeto, mas sínteses plenas, por assim dizer, ao inverso dos indícios mutilados reunidos no álbum fotográfico do etnólogo.

Tal como as podemos ver nas obras de André Thevet por exemplo, e como Léry as acrescentou desajeitadamente à sua segunda edição, essas sínteses de objetos, de personagens, de cenas, por mais aproximativas que nos pareçam hoje em dia, são imbuídas de humanidade. Penso especialmente no "Haüt", o preguiça de Thevet, de "semblante doce e sonhador", com um sorriso quase infantil ${ }^{7}$, o Haüt que Léry apresenta com riso irônico, num avatar diabolizado, na paisagem do "inferno brasileiro" povoado de demônios 
Revista de Antropologia, São Paulo, USP, 2000, v. 43 nº 2.

de todos os tipos (Léry, 1994: 383, fig. 20). Resultado mais ou menos bem acabado de uma bricolagem, essas imagens realizavam "a união do sensível e do inteligível” (Lévi Strauss, 1993: 32). Produziam um efeito de presença completamente diferente desses pedaços de vidas e de posturas imobilizadas e multiplicadas em sua rigidez pela objetiva do etno-fotógrafo.

\section{Saudades do Brasil}

Léry e Lévi-Strauss se encontram finalmente nessa busca retrospectiva de uma presença abolida. Um se posiciona da perspectiva da eternidade da salvação, que será confirmada no fim dos tempos, no julgamento final; o outro, à beira do "nada" que um dia resumirá, inevitavelmente, a história humana, quando "de um planeta ele mesmo condenado à morte", nalgum lugar dos redemoinhos de um cosmos imutável e silencioso, o homem terá desaparecido. De toda a história dos homens, dos cruzamentos de suas raças e dos traços de sua arte, nada restará. Última palavra das Mitológicas (1970: 621), esse "nada" (rien) não é nem o nada dos místicos espanhóis nem o nihil da teologia negativa. É o "alguma coisa", é a própria coisa, sem ser e sem forma, inerte. A poderosa e ampla sinfonia das Mitológicas se fecha como concluía o Ensaio sobre a desigualdade das raças humanas de Gobineau, com o espetáculo "de um mundo de semblante doravante impassível", sem futuro, sem passado, e portanto sem significação ${ }^{8}$. Esse é o nada branco fantasmado por Gobineau; esse é o inelutável não-ser que Lévi-Strauss, por sua vez, considera com uma serenidade bem lucreciana. O pessimismo de Léry o levava a ler nos mitos cosmogônicos dos índios o anúncio apocalíptico que lhes tinha sido feito; o pessimismo de Lévi-Strauss faz que ele dirija à terra sem homens um olhar de sombria serenidade.

Mas Léry, na terceira edição de 1585, acrescenta cinco frases musicais, para fazer ressoar nos ouvidos do leitor francês e suíço a extensão sonora de um mundo perdido. E Lévi-Strauss, no crepúsculo de uma carreira bem plena, "revela", quase no sentido fotográfico do termo, os arquivos visuais de suas missões do pré-guerra no Brasil. 
É necessária toda a vertigem da melancolia para fazer ressurgir, desse horizonte de morte - tenha a morte entrado na verdadeira vida ou no puro nada -, a presença efêmera e fascinante do outro. E é sempre um corpo que volta, com o cortejo de imagens, sons e sensações que o acompanha. Mais forte e mais insistente para Lévi-Strauss do que a prova fotográfica, o cheiro do creosoto que impregnava os cadernos do viajante traz imediatamente de volta, depois de mais de meio-século, "os cerrados e as florestas(...)" (1994b: 9).

Esse fenômeno de brusca reminiscência e a sinestesia que o acompanha lembram inevitavelmente a famosa madeleine de Proust. A madeleine do etnólogo seria o creosoto pouco comestível, líquido oleoso, transparente, desinfetante, composto de fenol e cresol, com que os cantis são besuntados “para protegê-los dos cupins e do bolor". A etimologia indica sutilmente que o creosoto conserva: formado pelas palavras gregas kreas, a "carne", e sôzein, "salvar", o creosoto literalmente paralisa a carne a caminho da podridão inelutável. Aqui metaforicamente, ele impede o passado de desaparecer. Traz de volta à vida o espectro carnal dos povos assassinados.

Para o leitor pouco familiarizado com a etnologia brasileira, o cheiro do creosoto evoca, não sem humor, a Busca do tempo perdido, que LéviStrauss noutro momento comentou. Mas para quem conhece as coisas do Brasil, leva novamente a Jean de Léry, o que não exclui Proust, é claro. Na História de uma viagem há uma observação, em tudo excepcional no século XVI, de uma correspondência olfativa. A farinha branca da mandioca, com o líquido esbranquiçado que dela escorre, "tem o mesmo cheiro que o amido, feito de puro fermento mergulhado longamente na água, quando ainda está fresco e líquido" (1994: 238). Léry não se contenta em fazer a aproximação, seguindo o costumeiro vaivém crítico entre lá e cá. Antes ele experimenta a analogia:

tanto que desde o meu retorno aqui, encontrando-me num local onde se fazia isso, o cheiro me fez lembrar o que se sente comumente nas casas dos selvagens, quando ali se fabrica farinha de raízes. (Ibidem) 
Revista de Antropologia, São Paulo, USP, 2000, v. 43 nº 2.

O Brasil selvagem surge num dia de lavagem de roupa numa aldeia da Borgonha. A reminiscência liga o que devia estar separado. Comunica e confunde instantaneamente o cá e o lá, o ontem e o hoje, abolindo qualquer intervalo, reparando toda perda, suscitando uma plenitude inaudita. Essa experiência de ordem metafísica, que será a da Busca, já é, de certo modo, a da História de uma viagem.

Com duas diferenças, no entanto: a fusão não une apenas dois tempos, mas também dois espaços separados, dois mundos situados a meses de navegação um do outro; e essa euforia repentina não é interpretada espontaneamente como uma promessa de eternidade. Para Léry, a única eternidade vem de Deus, como lembra a invocação final da História, tirada do cântico de Ana, mãe de Samuel, profeta e juiz de Israel:

não posso agora dizer, como a santa mulher mãe de Samuel, que experimentei que é o Eterno quem faz viver e faz morrer? Que faz descer à cova e faz dela sair? Sim, certamente, parece-me tão claro quanto o homem viver para o dia presente. (: 550)

O fenômeno da memória involuntária, em Léry, não traz nem salvação nem esperança, apenas a alegria indefinidamente repetida e sempre inesgotável de relembrar. Seu benefício se situa num plano puramente humano e terrestre. A dilatação do ser que o acompanha propicia um estado de felicidade instantânea, mas sem conseqüência alguma para o resto da vida. Recolhida na origem, em vez de voltada para o futuro, essa felicidade trai uma perda irreversível e tem um quê de tristeza. Mesma alegria, ligeiramente obnubilada de luto, quando o narrador, no auge da emoção - "com o coração palpitando" -, escuta a melopéia dos dançarinos cantando seus mitos de origem (1994: 403).

Essa ilusão de presença não é limitada ao instante, prolonga-se e instalase no tempo. De tanto contemplar os selvagens, "os grandes e os pequenos", Léry ainda os vê depois de ter-se afastado deles:

de modo que os vejo ainda diante dos olhos, terei deles para sempre a idéia e a imagem na mente. (: 233-4) 
A História de uma viagem mantém essa remanescência, e estende seus benefícios a outrem. A alucinação do estilo produz entre o narrador e o leitor uma emoção compartilhada, mas essa felicidade só pode ser realmente apreciada do terraço do céu, da perspectiva desse além daqui que é a salvação eterna, de que está praticamente excluído, segundo se constata, o índio. De forma que há em Léry, como haverá mais tarde em Lévi-Strauss, uma beleza do morto. O mundo dos Nambikwara é um mundo perdido, assim como a América de Léry é o Novo Mundo devastado descrito por Las Casas e Théodore de Bry, um mundo destruído pelos espanhóis, retomado pela idolatria sob a sua forma católica e de qualquer modo condenado à iminente perdição, segundo a profecia do anjo. É a esse preço que se pode contemplar de longe, e em toda a sua fragilidade preservada pela memória, o corpo perdido do índio. Seu "nu perdido", para usar a expressão de René Char (1971).

Tradução de Beatriz Perrone-Moisés.

\section{Notas}

1 As Singularidades de Thevet foram, na verdade, publicadas no final de 1557.

2 Ver acerca disso as observações de Perrine Galand-Hallyn (1995): “A própria teoria da 'representação viva' prevê sua denúncia como artifício" (: 101).

3 Lévi-Strauss refere-se aqui a episódios sangrentos dos enfrentamentos entre protestantes e católicos, na França, no final do século XVI. (N. da T.)

4 Para um aprofundamento da questão remeto a Lestringant (1999: cap. 5).

5 Ver a esse respeito o episódio resumido por Jean de Léry (1994: 381) a partir de Francisco Lopez de Gomara - cf. nota 1 da mesma página. 
Revista de Antropologia, São Paulo, USP, 2000, v. 43 nº 2.

6 Tomo essas distinções emprestadas de Lévi-Strauss (1993: 32-3).

7 Prancha da Cosmographie Universelle de André Thevet, t. II, f. 941v. Reproduzida e comentada em Lestringant (1991: 337). O comentário é de Gustave Flaubert, Carnet 16.

8 Essa filiação foi reconhecida - e até reivindicada - por Lévi-Strauss em Regarder, écouter, lire (1993: 147-8).

\section{Bibliografia}

CALVIN, J.

1961 "De la congnossaince de Dieu", in PANNIER, J. (org.), Insitution de la Religion Chretienne, t. I, Paris, Les Belles Lettres, p. 52.

\section{CHAR, R.}

1971 Le nu perdu, Paris, Gallimard.

CURTIUS, E. R.

1956 La littérature européenne et le Moyen Age latin, Paris, PUF, cap. XVI.

DERRIDA, J.

1967 "La violence de la lettre: de Lévi-Strauss à Rousseau", in De la grammatologie, Paris, Minuit, pp. 149-202.

\section{GALAND-HALLYN,P.}

1995 Les yeux de l'éloquence, Orleans, Paradigme.

HALLYN,F.

1994 Le sens des formes. Études sur la Renaissance, Genebra, Oroz, p. 30.

$$
-101-
$$


Frank Lestringant. De Jean de Léry a Claude Lévi-Strauss

\section{LESTRINGANT, F.}

1991 André Thevet, cosmographe des derniers valois, Genebra, Oroz.

1999 Jean de Léry ou l'invention du sauvage, Paris, Champion, cap. 5.

LÉRY, J.DE

1994 Histoire d'un voyage faict en la terre du Brésil, Paris, LGF, Bibliothèque Classique.

\section{LÉVI-STRAUSS, C.}

1970 "L’homme nu”, in Mythologiques IV, Paris, Plon.

1976 Antropologia estrutural dois, trad. Sonia Wolosker, Rio de Janeiro, Tempo Brasileiro.

1993 Regarder, écouter, lire, Paris, Plon.

1994a "Sur Jean de Léry", in LÉRY, J. de. Histoire d'un voyage faict en la terre du Brésil, Paris, LGF, Bibliothéque Classique.

1994b Saudades do Brasil, trad. Paulo Neves, São Paulo, Companhia das Letras.

1996 Tristes trópicos, trad. Rosa Freire d'Aguiar, São Paulo, Companhia das Letras.

MONTAIGNE.

1965 Essais, 6. ed., Villey/Paris, PUF.

PLATÃO.

1950 Phèdre, t. II, trad. Léon Robin, Paris, Bibliothèque de la Pléiade.

SOULIÉ, M.

1977 L'inspiration biblique dans la poésie religieuse d'Agrippa d'Aubigné, Paris, Klincksieck. 
Revista de Antropologia, São Paulo, USP, 2000, v. 43 nº 2.

ABSTRACT: A comparison between History of Two Travels to Brazil, by Jean de Léry, and Tristes Tropiques, by Claude Lévi-Strauss, brings up many parallels between the authors and between their narratives about Brazil. De Léry's relation with the country, his description of the Indians and his way of structuring the text turn him into a Lévi-Strauss' predecessor. Instead of retrieving de Léry's narrative, Lévi-Strauss establishes with it a dialog in which on can perceive the authors' divergent points of view. These involve the travellers' nosthalgic memories about their stay in the New World.

KEY-WORDS: Jean de Léry, Claude Lévi-Strauss, travel narratives, images of the Indians.

Recebido em novembro de 1999. 